\title{
Lithic refitting and the analysis of Middle Palaeolithic settlement dynamics: a high-temporal resolution example from El Pastor rock shelter (Eastern Iberia)
}

\author{
Jorge Machado ${ }^{1} \cdot$ Alejandro Mayor $^{1,2} \cdot$ Cristo M. Hernández ${ }^{1,3} \cdot$ Bertila Galván $^{1,4}$
}

Received: 26 June 2018 / Accepted: 10 May 2019

(C) Springer-Verlag GmbH Germany, part of Springer Nature 2019

\begin{abstract}
Archaeostratigraphic study of the Stratigraphic Unit IV from the Middle Palaeolithic site of El Pastor (Eastern Iberia) has resulted on the definition of high-resolution analytical units mostly corresponding to "micro-palimpsests" formed during more than a single human occupation. Analysis of these anthropogenic assemblages has suggested their interpretation as remains from several short-term occupations performed by MIS 3-4 Neanderthals. In this paper, we present an evaluation of this interpretative proposal, focusing on the technical and spatial study of lithic refits. Our aim is to present an empirical work that also contributes to the methodological discussion about refitting studies and behavioural interpretation related to Palaeolithic settlement dynamics.
\end{abstract}

Keywords Middle Palaeolithic $\cdot$ Neanderthals $\cdot$ Settlement dynamics $\cdot$ El Pastor $\cdot$ Lithic assemblage formation $\cdot$ Lithic refitting

\section{Introduction}

Current research into Middle Palaeolithic has widely highlighted formation processes analysis as the most significant requirement for the suitable behavioural and cultural interpretation of archaeological assemblages (e.g. Adler et al. 2003; Conard 2001; Goldberg and Berna 2010; Goldberg and Macphail 2005; Machado et al. 2015; Mallol and Hernández 2016; Mallol and Mentzer 2015; Mallol et al. 2013a, 2013b; Martínez et al. 2015; Vaquero 2008). These efforts have been principally focused on the definition of more temporally bounded analytical frameworks that allows approaching past human behaviours at time scales of analysis as close as possible

Jorge Machado

jorgemachado85@gmail.com

1 Grupo de Investigación Sociedades Cazadoras-Recolectoras Paleolíticas; Departamento de Prehistoria, Arqueología, Antropología e Historia Antigua; Sección de Geografía e Historia; Facultad de Humanidades, Universidad de La Laguna, Guajara Campus - San Cristóbal de la Laguna, 38071 Santa Cruz de Tenerife, Spain

2 Àrea de Coneixement de Prehistòria; Departament de Prehistòria, Arqueologia, Història Antiga, Filologia Grega i Filologia Llatina; Facultat de Filosofia i Lletres, Universitat d'Alacant, Sant Vicent del Raspeig Campus - Sant Vicent del Raspeig, 03690 Alacant, Spain to the "ethnographic time" (e.g. Bargalló et al. 2016; Carrancho et al. 2016; Chacón et al. 2015; Gabucio et al. 2017, 2018; Henry 2012; Machado et al. 2017; Martínez et al. 2004; Romagnoli and Vaquero 2016; Rosell et al. 2012; Sánchez et al. 2017; Sañudo et al. 2015; Spagnolo et al. 2016; Vallverdú et al. 2005; Vaquero and Pastó 2001; Vaquero et al. 2012a, 2012b, 2015). This goal remains elusive given the difficulty that entails the accurate identification and ordering of processes of overlapping, mixing and removing of natural and anthropogenic materials that formed the archaeosedimentary deposits (Audouze and Enloe 1997; Bailey 2007; Binford 1980, 1981; Isaac 1981; Lucas 2012; O’Connell 1987; Schiffer 1985; Shott 2008; Stern 1993, 1994).

3 Área de Didáctica de Ciencias Sociales; Departamento de Didácticas Específicas; Facultad de Educación, Universidad de La Laguna, Edificio Central Campus - San Cristóbal de la Laguna, 38200 Santa Cruz de Tenerife, Spain

4 Área de Conocimiento de Prehistoria; Unidad de Docencia e Investigación de Prehistoria, Arqueología e Historia Antigua; Departamento de Prehistoria, Arqueología, Antropología e Historia Antigua; Sección de Geografía e Historia; Facultad de Humanidades, Universidad de La Laguna, Guajara Campus - San Cristóbal de la Laguna, 38071 Santa Cruz de Tenerife, Spain 
To face such methodological constraints related to the widely noted "palimpsest problem", lithic refits have shown an important informative potential for the recognition of temporal and spatial relationships between areas and material accumulations. Also, their study has been commonly used for assessing the impact of post-depositional alteration on Palaeolithic deposits (e.g. Bleed 2002; Husmann 1990; Schmider and De Croisset 1990; Sumner and Kuman 2014; Takakura 2018; Vaquero et al. 2001).

It should be also highlighted that lithic refits are key indicators for high-resolution approaches to assemblage formation, since their depositional stories are clearly related to specific human actions framed within a single occupation episode. Regarding the study of behavioural and cultural dynamics, lithic refits do also provide significant data about technical knowledge and skills of Palaeolithic hominins. Furthermore, the combined study of their technical and spatial features has been revealed as a potential tool for approaching site function and duration of Palaeolithic human occupations (e.g. Adler et al. 2003; Amick 2007; Conard and Adler 1997; López et al. 2017; Machado and Pérez 2016; Machado et al. 2013; Romagnoli et al. 2016, 2017; Thiébaut et al. 2010; Vaquero 2008, 2011; Vaquero et al. 2012a, b, 2017).

The present work is a fine-grained approach to the Stratigraphic Unit IV (SU IV) from the Middle Palaeolithic site of El Pastor (Eastern Iberia) aimed to assess the behavioural meaning of lithic refits within high-temporal resolution contexts. This study has been mostly supported on the archaeostratigraphic isolation of high-resolution analytical frameworks containing lithic, faunal and combustion remains. Spatial analysis of these records was performed within each isolated analytical unit. Lithic study was made from an integrated perspective which included technical and spatial analyses of raw material units (RMUs) and refits. Identified refitting sets have provided information about assemblage formation useful for the recognition of post-depositional processes and behavioural dynamics developed by MIS 3-4 Neanderthals. Discussion about the significance of El Pastor lithic refits as indicators of the number, duration and function of human occupations has been also included.

Our results suggest that the studied records were shaped by at least 9 short-term occupations. This analysis has also reinforced the consideration of a hearth-related assemblage as the most reliable material trace from a single human occupation episode at Middle Palaeolithic contexts (see Machado et al. 2015).

\section{Materials and methods}

\section{Overview of El Pastor rock shelter and the stratigraphic sequence}

El Pastor is a rock shelter $\left(60 \mathrm{~m}^{2}\right)$ located at $820 \mathrm{~m}$ above sea level in the Mariola mountains, near to the city of Alcoy (Alicante, Eastern Iberia) (Galván et al. 2009; Machado et al.
2013; Molina et al. 2010; Pérez et al. 2017; Vidal et al. 2015, 2017). This rock shelter represents an eroded karstic tube within a larger karstic network linked to the phreatic activity of the nearby Serpis River. Its structure is made up of a limestone cobble conglomerate framed within a Miocene Tortonian sedimentary geological context (Fig. 1).

The sedimentary sequence known to date is $1.5 \mathrm{~m}$ thick and has been divided into six Stratigraphic Units (SU I-VI) according to macroscopic and micromorphological sedimentological criteria. It was mainly formed by gravitational deposition of relatively fresh micritic calcite and fossiliferous limestone cobbles coming from the dismantling of the rock shelter. A very low amount of clay is only presented as fine coatings and infillings.

The stratigraphic sequence is as follows (from base to top) (Fig. 2):

- SU VI (unknown thickness): It has only been recognised in a test pit near the back wall. It is composed of dark brown siltysandy sediment with $40 \%$ of clasts and gravel. Combustion features associated to anthropogenic bone remains, lithics and charcoal fragments have been recorded in this unit.

- SU V (25 cm thick): Excavation of this layer is currently in process. It is composed of dark brown silty-sandy sediment with a similar proportion of gravel to SU VI. Very few lithic and faunal remains have been recovered so far.

- SU IV (70 cm thick): This is archaeologically rich stratum formed by alternation of pebbly (Lithostratigraphic Units IVa, IVc, IVe and IVg) and finer-grained, pale brown sandy-gravelly layers (Lithostratigraphic Units IVb, IVd and IVf). Preliminary thermoluminescence dates have indicated that archaeological assemblages from this unit are older than $75 \pm 10.000 \mathrm{ky}$ (Hernández et al. 2014). The present analysis focuses on anthropogenic lithic and faunal remains associated to 9 combustion structures recovered from Lithostratigraphic Units IVb, IVc and IVd.

- SU III (3-12 cm thick): This is a thin, discontinuous, locally cemented pale brown layer of calcareous sand and gravel. Archaeological finds are very scarce relative to the other units.

- SU II (8-13 cm thick): It is a small relict of dark brown sediment located in the NW corner of the excavation area, truncated by SU I. A single combustion structure with bone fragments around has been recorded in this unit.

- SU I (30-65 cm thick): It was formed by an indeterminate number of episodes of Holocene sedimentation. Several handmade pottery fragments and Palaeolithic remains in secondary position have been recovered from this unit.

\section{Archaeostratigraphic analysis}

Approaching archaeological assemblage formation processes entails the definition of temporally bounded analytical frameworks as closer as possible to the temporal scale within which human behaviours occurred (i.e. "ethnographic time-scale"). This task 
Fig. 1 Overview of the geological context and the Pastor rock shelter; geographic position of the site within the Iberian Peninsula
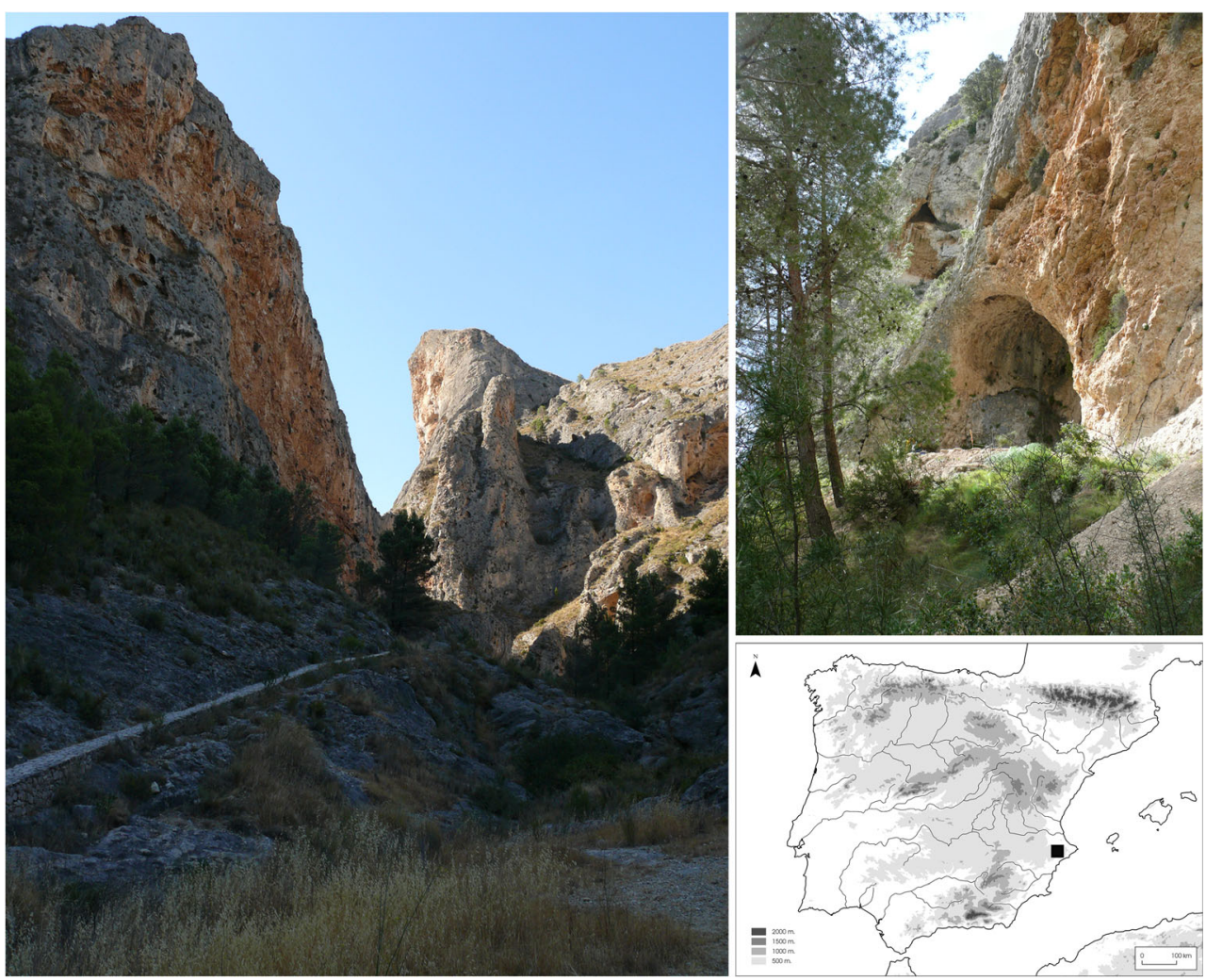

has been performed using archaeostratigraphic methods based on the analysis of the location of lithic, faunal and combustion remains recovered from the Lithostratigraphic Units IVb, IVc and IVd (Figs. 2, 3, 4 and 5). Further, it is also significant to highlight at this point that this analysis is based on an excavation surface corresponding to the almost entire potential occupational area.

Archaeological record was three-dimensionally plotted in order to isolate single beds of archaeostratigraphically correlated anthropogenic assemblages within the SU IV deposit (i.e. our Archaeostratigraphic Units). The identification of archaeologically sterile sediments representing time without human activity and the stratigraphic location of the top of combustion features (black layers and accumulations of burnt limestone cobbles) have been considered as chief archaeostratigraphic landmarks for this purpose (Mallol et al. 2013a; Stevenson 1991). All 3D plots and longitudinal and cross-sectional profiles were performed considering the entire excavation surface and the microtopographical features and natural sedimentation slope approached during fieldwork, using ArcGIS® software (ArcMap v10.2.2 and ArcScene v10.2.2).

\section{Lithic analysis}

Lithic records from each of the isolated high-resolution analytical units were studied from a depositional perspective in order to approach temporal and behavioural indicators
Fig. 2 Picture showing relationships between stratigraphic, lithostratigraphic and archaeostratigraphic data from Pastor
ABRIC DEL PASTOR

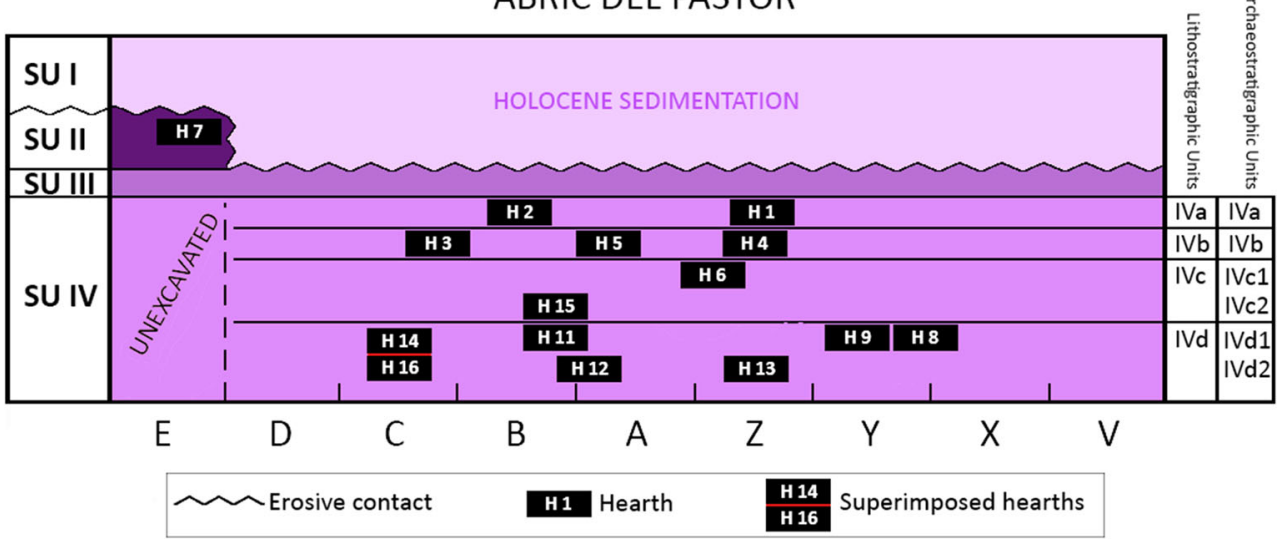




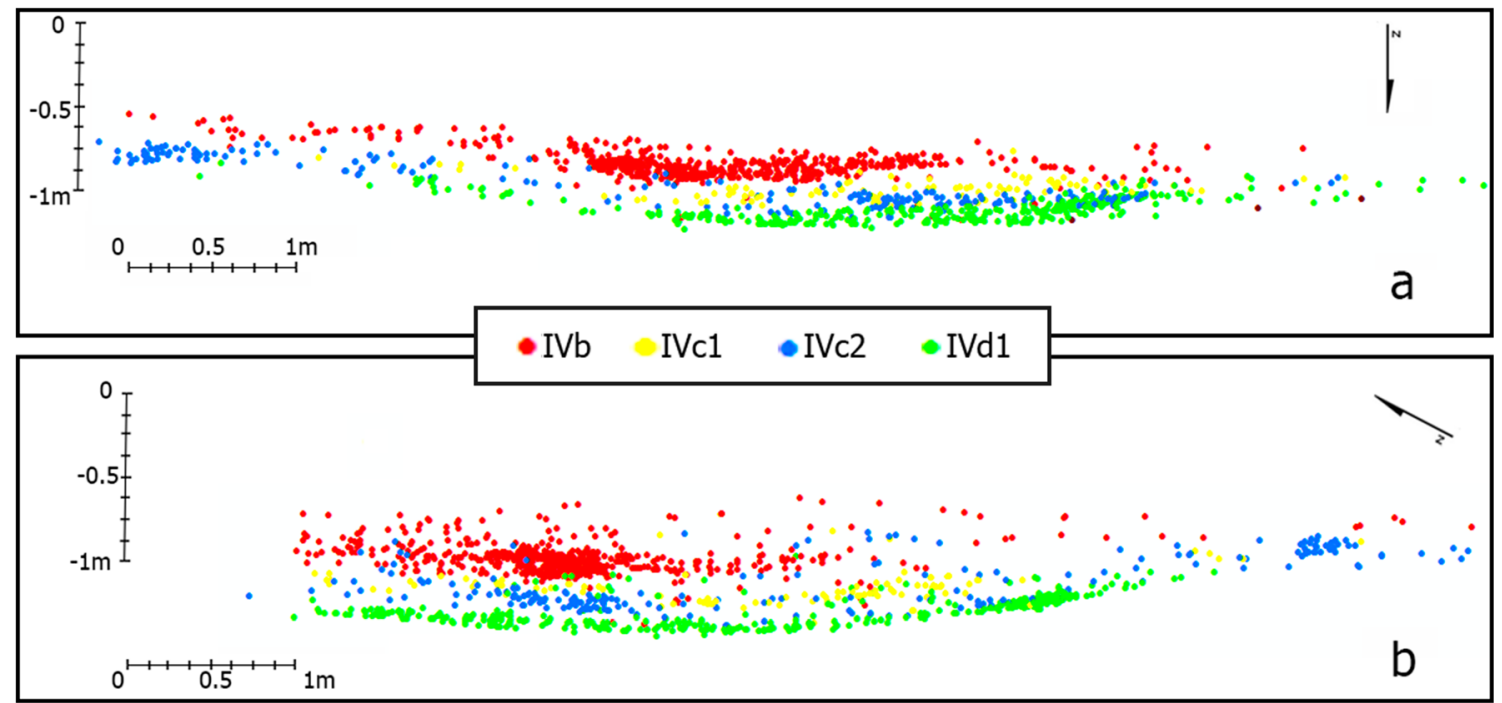

Fig. 3 Spatial distribution of faunal and lithic remains from Pastor Stratigraphic Units IV. a South-to-north general cross-section. b East-to-west general cross-section

involved on their formation. This analysis was principally focused on technical features and spatial distributions shown by RMUs (Table 1) (e.g. Adler et al. 2003; Conard and Adler 1997; Roebroeks 1988; Vaquero 2008) and refitting sets.

RMUs were defined from a macroscopic comparative study of cortex, opacity, halos, inclusions, grain size, texture and colour presented by geological samples and archaeological specimens. These diagnostic physical features revealed a high degree of variability that has favoured the recognition of RMUs and refits. RMU approach was also needed to recognise specific knapping sequences performed within and outside the site, to discern the way in which lithic materials were

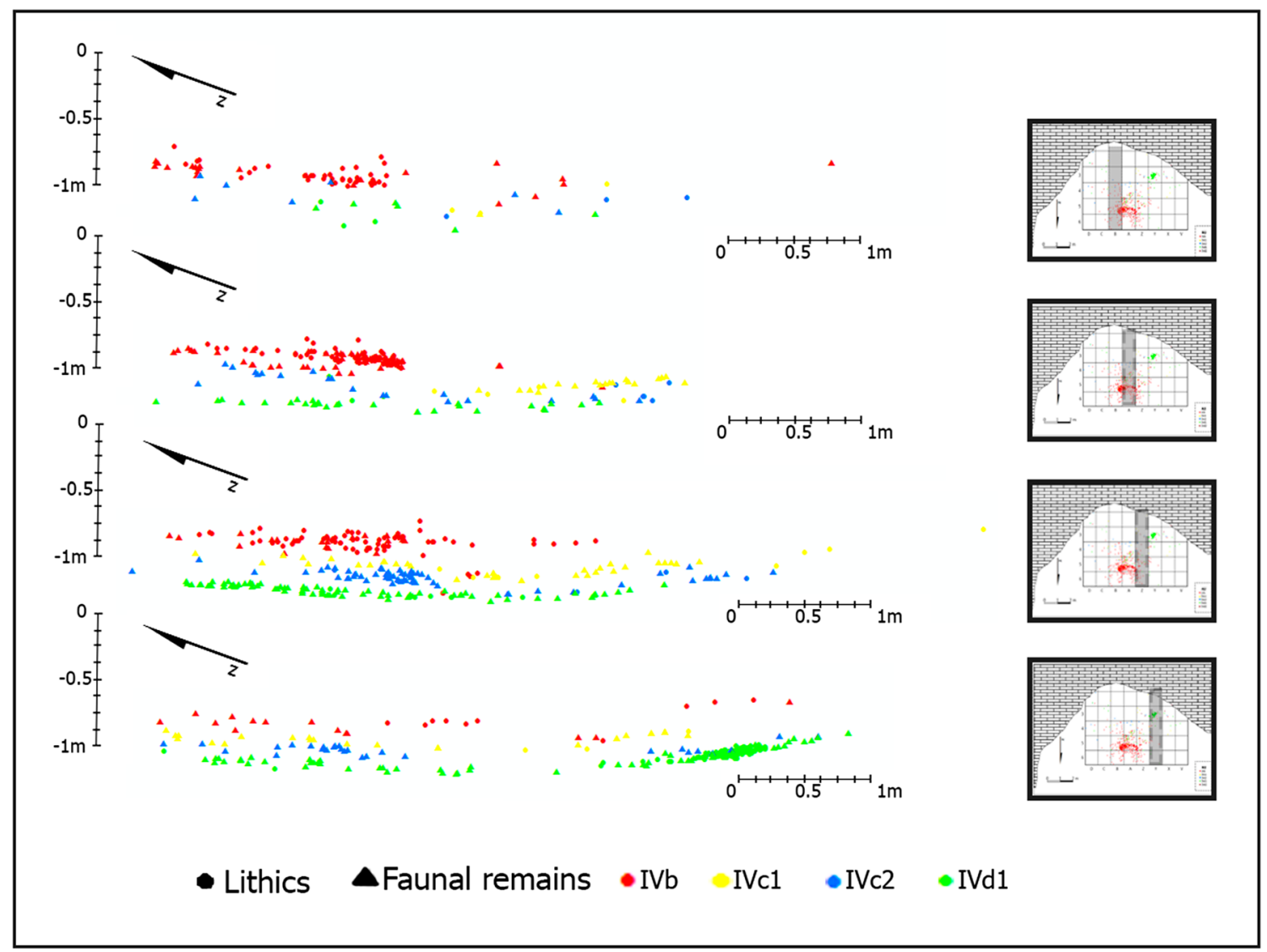

Fig. 4 East-to-west cross-sections of the Pastor IV archaeological assemblage 

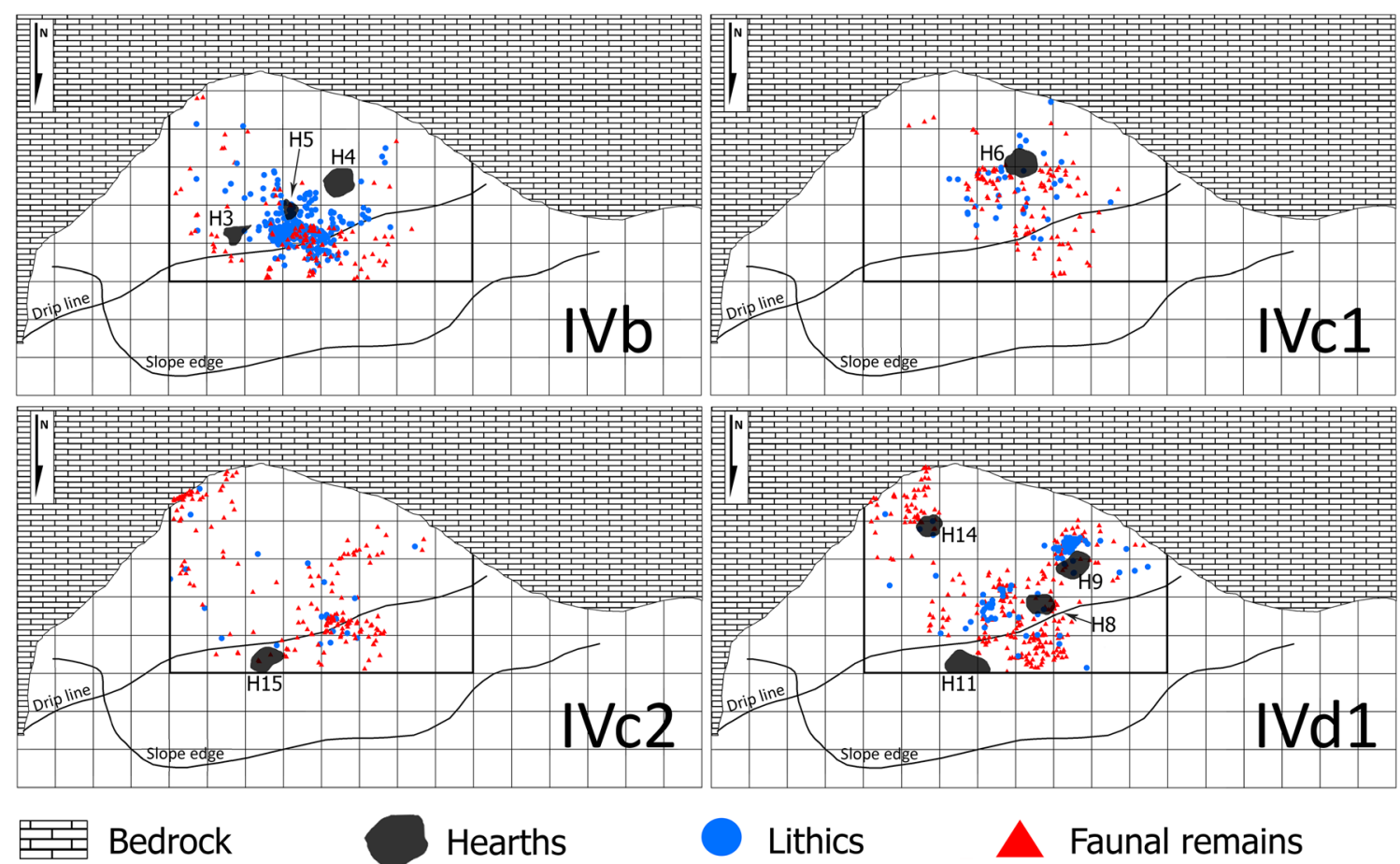

Hearths

\section{Lithics}

Faunal remains

Fig. 5 General spatial distribution of lithic, faunal and combustion remains sorted by archaeostratigraphic units (1 $\mathrm{m}^{2}$ squares)

transported and discarded and to establish spatial and temporal relationships among particular areas of the excavation surface and anthropogenic accumulations.

Refitting sets were classified according to the stage of the reduction of nodules that they represent (cortex removal, plein débitage or final reduction of cores). Then, technological methods related to the production of these refitting groups were recognised. It was also checked if a single reduction scheme was applied (or not) to produce refitting sets from RMUs including two or more of them. Further, the type of blanks that are absent among refits and/or the remaining lithics from each RMU was identified.
Table 1 Naming and general quantitative data of studied refitting sets

\begin{tabular}{llllll}
\hline RMU & Signature* & Refits & $\begin{array}{l}\text { Refitted } \\
\text { specimens }\end{array}$ & $\begin{array}{l}\text { Non-refitted } \\
\text { specimens }\end{array}$ & $\begin{array}{l}\text { Refitted/non-refitted specimens } \\
(\%)\end{array}$ \\
\hline B1 & S_B2 & 4 & 10 & 14 & $41.67 / 58.33$ \\
B2 & B_B4 & 1 & 2 & 1 & $66.66 / 33.33$ \\
B3 & M_B2 & 1 & 4 & 4 & $50.00 / 50.00$ \\
B4 & B_B2 & 1 & 3 & 12 & $20.00 / 80.00$ \\
B5 & B_B1 & 5 & 25 & 283 & $08.12 / 91.88$ \\
B6 & B_B3 & 1 & 1 & 0 & $100.00 / 00.00$ \\
B7 & M_B1 & 2 & 34 & 52 & $39.53 / 60.47$ \\
D1 & B_D2 & 1 & 2 & 2 & $50.00 / 50.00$ \\
D2 & S_D4 & 1 & 2 & 0 & $100.00 / 00.00$ \\
D3 & S_D1 & 1 & 2 & 9 & $18.18 / 81.82$ \\
D4 & B_D1 & 4 & 30 & 56 & $34.88 / 65.12$ \\
D5 & S_D5 & 3 & 11 & 25 & $30.56 / 69.44$ \\
D6 & S_D6 & 1 & 3 & 0 & $100.00 / 00.00$ \\
Total & & 25 & 129 & 458 & $129 / 458$ specimens \\
Proportion(\%) & & 21.98 & 78.02 & $21.98 / 78.02 \%$ \\
\end{tabular}

*The signatures are formed by the kind of flint ( $S$, Serreta; $M$, Mariola; $B$, Beniaia), the Lithostratigraphic Unit (B from Ivb, D from IVd) and an id number. These signatures were used in Machado et al. (2013) 


\section{Spatiotemporal analysis and behavioural inference}

This approach focuses on the study of spatial and temporal relationships between archaeological materials framed within each of the defined archaeostratigraphic units. Its main goal is the identification of anthropogenic depositional events representing human activities and determines - as far as possible - their temporal relationships. This approach aims to achieve two objectives:

1. To evaluate if our archaeostratigraphic units were formed during a single occupation episode or more.

2. To evaluate if inferences about site function and duration of human occupations could be proposed through the studied records.

Following these purposes, we have performed a behavioural approach from two different time scales of analysis:

- The "assemblage level". The archaeological record from each archaeostratigraphic unit is considered as a whole for behavioural interpretation. This is the less-detailed time scale of analysis reachable through a behavioural approach (i.e. analogous to formation lengths of our analytical units), since only general trends can be identified this way (Vaquero et al. 2012a).

- Analysis of single activities. This analysis is based on the recognition of single-activity episodes, which represent the highest temporal resolution achieved by behaviouraloriented research (Lucas 2012). Behavioural inference at this level of analysis is based on the study of spatial and technical features of raw material units and refits in the case of lithics.

Applying this approach, we could observe two kinds of indicators of relative diachrony framed within a single occupation or within more of them (intra-occupational and interoccupational diachronic indicators, respectively). Indicators of inter-occupational diachrony are easily observable from the described "assemblage level" approach. Overall, we consider as such the amount of anthropogenic bones, lithics and combustion remains, as well as the variety of faunal taxa and geological raw material sources evidenced by them. Among lithic artefacts, the number of RMUs and refits and the presence of recycling evidences are also considered as indicators of inter-occupational diachrony. A high scattering degree of archaeological remains is also interpreted as such, as it has been widely highlighted elsewhere (e.g. Binford 1980, 1981; Isaac 1981; Schiffer 1985; Stern 1994).

Defined analysis of single activities provides us the temporal scale of analysis needed to identify indicators of intraoccupational diachrony. That is because an ideal approach to the number, duration and function of occupation episodes only could be possible through an accurate recognition of single activities and their temporal relationships. Therefore, the following has been considered as indicators of intra-occupational diachrony; the presence of clear spatial relationships between hearths and bone and lithic remains resulted from single activities, the lowest degrees of spatial scattering displayed by anthropogenic material, homogeneity among lithic raw materials and faunal taxa and a low amount and variety — or even the absence - of combustion features, RMUs and refits.

Performed spatiotemporal analysis of refitting sets from our analytical units has been focused on unravelling their signification as relative diachronic indicators. The following variables have been used for this purpose: general spatial distribution of refitted remains, their spatial relationships with other anthropogenic materials and their spatial distribution sorted by technical criteria.

\section{Results}

Several Archaeostratigraphic Units (AUs) were defined within El Pastor SU IV deposit by a previous analysis (AUs IVa, IVb and IVc1), which has been already published elsewhere (Machado et al. 2013). The definition of the remaining AUs resulted from the present study (AUs IVc2 and IVd1) (Figs. 3 and 4). Results from the performed integrated analysis of spatial and technical features shown by RMUs and refits are also empirical contributions from this work.

Lithic record from the SU IV is integrated by 715 flint artefacts. A total of 587 have been ascribed to any RMU, and 129 of them have been refitted in 25 refitting sets (Table 2). These refits were classified into three groups according to their technical features within the framework of their corresponding RMUs:

- Single short knapping sequences: This type of refitting sets is integrated by a small amount of items representing a single short reduction sequence. They are the only refits from their respective RMU in all cases. Four refitting sets from the AU IVb (R5-7 and R13) and other four ascribed to the AU IVd1 (R15-17 and R25) correspond to this refit-type.

- Several short knapping sequences: This group is formed by at least two independent refitting sets belonging to the same single raw material mass. Refits from this group were recovered from the AUs Ivb (R1-4) and IVd1 (R22-24) (Table 3).

- Almost entire knapping sequences: This type of refitting set represents the almost total reduction of a single nodule. We have identified three of them in this work (R8-12 and R14a-c from the AU Ivb and R18-21from the AU Ivd1) (Table 3).

Archaeological contents and results from performed analyses for each AU are presented below.

\section{Archaeostratigraphic unit Ivb}

Anthropogenic assemblage from the AU IVb is the widest one and comprises 3 hearths (H3, H4 and H5), 445 lithics and 159 faunal remains (Table 4). Among lithics, 79 specimens have 
Table 2 General technological and quantitative data sorted by archaeostratigraphic units

\begin{tabular}{|c|c|c|}
\hline Archaeostratigraphic unit Ivb & Levallois & Non-Levallois \\
\hline $\begin{array}{l}\text { (466 lithic finds) flint types: } 341 \text { Beniaia, } 97 \text { Mariola, } 28 \text { Serreta; } 5 \\
\text { retouched flakes }\end{array}$ & production & production \\
\hline Cores & 5 & 3 \\
\hline Cortical flakes & 5 & 66 \\
\hline Flakes & 108 & 269 \\
\hline Core-flakes & & 2 \\
\hline Fragments & & 8 \\
\hline Archaeostratigraphic unit IVc1 & Levallois & Non-Levallois \\
\hline $\begin{array}{l}\text { (22 lithic finds) flint types: } 7 \text { Beniaia, } 1 \text { Mariola, } 14 \text { Serreta; } 7 \text { retouched } \\
\text { flakes }\end{array}$ & production & production \\
\hline Cores & & 4 \\
\hline Cortical flakes & & 9 \\
\hline Flakes & 7 & \\
\hline Fragments & & 2 \\
\hline Archaeostratigraphic unit IVc2 & Levallois & Non-Levallois \\
\hline $\begin{array}{l}\text { (18 lithic finds) flint types: } 3 \text { Beniaia, } 12 \text { Mariola, } 2 \text { Serreta, } 1 \text { unknown; } \\
5 \text { retouched flakes }\end{array}$ & production & production \\
\hline Cortical flakes & 1 & 1 \\
\hline Flakes & 8 & 8 \\
\hline Archaeostratigraphic unit IVd1 & Levallois & Non-Levallois \\
\hline $\begin{array}{l}\text { (198 lithic finds) flint types: } 84 \text { Beniaia, } 16 \text { Mariola, } 92 \text { Serreta, } 6 \\
\text { indeterminate; } 5 \text { retouched flakes }\end{array}$ & production & production \\
\hline Cores & 2 & 2 \\
\hline Cortical flakes & & 67 \\
\hline Flakes & 26 & 93 \\
\hline Core-flakes & & 3 \\
\hline Indeterminate & & 5 \\
\hline
\end{tabular}

been refitted into 15 refitting sets (R1-15) belonging to 7 RMUs (RMUs B1-7) (Table 1).

Most of the items comprising IVb refitting sets formed a main accumulation spatially related to one of the combustion structures (Figs. 5, 6, 7 and 8). This is the case of refitting sets R1-4 (RMU B1), R6 (RMU B3), R7 (RMU B4), R8-12 (RMU B5) and R14a-c (RMU B7) (Table 3). However, it should be noted that some of their elements are scattered away from the principal clusters. Usually, the core is the most distant element, as it can be observed in the case of R14b or R12. Finally, it should be also highlighted that refit R13 (RMU B6) is the only one that presents a significant vertical scattering caused by postdepositional processes (Machado et al. 2013).

Further, specific spatial relationships between RMUs including refitting sets and the top of burnt surfaces from combustion structures have been revealed by a detailed archaeostratigraphic study of their vertical locations. This analysis has determined the existence of at least three depositional events including lithic refits and a single hearth (RMUs B5 and B4 and H5 belong to the oldest depositional episode, RMU B7 and H3 to the intermediate one and RMUs B1 and B2 and $\mathrm{H} 4$ to the most recent one) (Table 3).

\section{Archaeostratigraphic unit Ivc1}

Anthropogenic record from the AU IVc1 is structured as a hearth-related assemblage formed by the hearth H6, 95 faunal remains (Table 4) and 22 lithics without any refitting set (Table 2). This lithic assemblage is integrated by 6 RMUs and 2 single tools transported to the site already configured.

\section{Archaeostratigraphic unit Ivc2}

Anthropogenic record from the AU IVc2 is integrated by an archaeostratigraphically correlated assemblage formed by 18 lithics, 184 faunal remains (Table 4) and a single combustion feature (H15). This latter is shaped by an accumulation of burnt limestone cobbles and blocks that represent the material trace of a partially dismantled hearth (Fig. 5). This combustion feature and the original distribution of several archaeological remains have been slightly altered by the gravitational 
Table 3 Technical features and main archaeostratigraphic information from refitting sets and RMUs

\begin{tabular}{|c|c|c|c|c|c|}
\hline RMU & Group & Refit & $\begin{array}{l}\text { Tech. } \\
\text { features }\end{array}$ & $\begin{array}{l}\text { Relation to } \\
\text { hearth }\end{array}$ & Spatial features \\
\hline B1 & $\begin{array}{c}\text { Several short } \\
\text { sequences }\end{array}$ & $\begin{array}{l}\mathrm{R} 1 \\
\mathrm{R} 2 \\
\mathrm{R} 3 \\
\mathrm{R} 4\end{array}$ & $\begin{array}{l}\text { RCL } \\
\text { Uni non-L } \\
\text { RCL } \\
\text { RCL }\end{array}$ & $\mathrm{H} 4$ & $\begin{array}{l}\text { Main accumulation with few } \\
\text { elements away }\end{array}$ \\
\hline B2 & - & R5 & $\begin{array}{l}\text { RCL-like } \\
\text { flake }\end{array}$ & - & \\
\hline B3 & Short seq. & R6 & RCL & H4 & \\
\hline B4 & Short seq. & R7 & Uni non-L & $\mathrm{H} 3$ & \\
\hline B5 & $\begin{array}{l}\text { Almost complete } \\
\text { nodule }\end{array}$ & $\begin{array}{l}\text { R8 } \\
\text { R9 } \\
\text { R10 } \\
\text { R11 } \\
\text { R12 }\end{array}$ & $\begin{array}{l}R C L \\
\mathrm{RCL} \\
\mathrm{RCL} \\
\mathrm{RCL} \\
\mathrm{RCL}^{1}\end{array}$ & H5 & \\
\hline B6 & Short seq. & $\mathrm{R} 13$ & Non-L & $\mathrm{H} 4 ?$ & Horizontal and vertical dispersion \\
\hline B7 & $\begin{array}{l}\text { Almost complete } \\
\text { nodule }\end{array}$ & $\begin{array}{l}\text { R14a } \\
\text { R14b } \\
\text { R14c }\end{array}$ & $\begin{array}{l}\text { Unipolar } \\
\text { Non-L } \\
\text { RCL }^{2}\end{array}$ & $\mathrm{H} 3$ & $\begin{array}{l}\text { Main accumulation with few } \\
\text { elements away }\end{array}$ \\
\hline $\begin{array}{l}\text { D1 } \\
\text { D2 }\end{array}$ & $\begin{array}{l}\text { Short seq. } \\
\text { Short seq. }\end{array}$ & $\begin{array}{l}\mathrm{R} 15 \\
\mathrm{R} 16\end{array}$ & $\begin{array}{l}\text { RCL } \\
\text { Uni non-L }\end{array}$ & H9 & Main accumulation \\
\hline D3 & Short seq. & $\mathrm{R} 17$ & $\mathrm{RCL}$ & $\mathrm{H} 10$ & \\
\hline D4 & $\begin{array}{l}\text { Almost complete } \\
\text { nodule }\end{array}$ & $\begin{array}{l}\text { R18 } \\
\text { R19 } \\
\text { R20 } \\
\text { R21 }\end{array}$ & $\begin{array}{l}\text { Uni non-L } \\
\text { Uni non-L } \\
\text { Orth non-L } \\
\text { Uni non-L }\end{array}$ & H9 & \\
\hline D5 & $\begin{array}{c}\text { Several short } \\
\text { sequences }\end{array}$ & $\begin{array}{l}\mathrm{R} 22 \\
\mathrm{R} 23 \\
\mathrm{R} 24\end{array}$ & $\begin{array}{l}\text { Cortex } \\
\text { removal } \\
\text { RCL } \\
\text { Uni }^{2,4}\end{array}$ & & \\
\hline D6 & Short seq. & $\mathrm{R} 25$ & $\begin{array}{l}\text { Cortex } \\
\text { removal }\end{array}$ & & \\
\hline
\end{tabular}

${ }^{1}$ Final more secant extractions. ${ }^{2}$ Small-sized products. ${ }^{3}$ Elonged products. ${ }^{4}$ One of these 7 flakes is Kombewa $R M U$, raw material unit; tech., technological; Uni, unidirectional extractions; $R C L$, recurrent centripetal Levallois; non- $L$, non-Levallois; orth, orthogonal extractions
Table 4 Available quantitative faunal data from Pastor SU sorted by Lithostratigraphic Units (Machado et al. 2013; Sanchis et al. 2015; Leopoldo J. Pérez pers. com. 2019). Bone remains recovered from the sieve are also included

\begin{tabular}{llll}
\hline Family & \multicolumn{2}{l}{ Lithostratigraphic Unit } \\
\cline { 2 - 4 } & IVb & IVc & IVd \\
\hline Bovidae & 14 & 34 & 5 \\
Canidae & 1 & - & 1 \\
Caprinae & - & - & 22 \\
Cervidae & 8 & 2 & 18 \\
Corvidae & 2 & - & 2 \\
Equidae & 5 & 2 & - \\
Leporidae & 3 & 2 & 8 \\
Rhinocerotidae & 6 & - & - \\
Suidae & 1 & - & - \\
Testudinidae & 5 & 108 & 129 \\
Indeterminate & 114 & 214 & 136 \\
Total & 159 & 362 & 321 \\
\hline
\end{tabular}

deposition of limestone cobbles from the roof that formed the top of the Lithostratigraphic Unit IVc.

Lithic record from the AU IVc2 is the less numerous among defined AUs within the SU IV. It includes 3 RMUs without any refitting set and 5 transported tools (one of them is made on an unknown flint type) (Table 2).

\section{Archaeostratigraphic unit Ivd1}

Anthropogenic record from the AU IVd 1 is formed by 198 lithics, 228 faunal remains (Table 4) and four combustion structures (H8, H9, H11 and H14) (Fig. 5).

A total of 132 lithics belongs to 6 RMUs (RMUs D1-D6) and 50 of them have been refitted into 11 refitting sets (R1525) (Tables 1 and 5). Most of the items from these refitting sets were located in a single main accumulation (Figs. 5 and 9). 


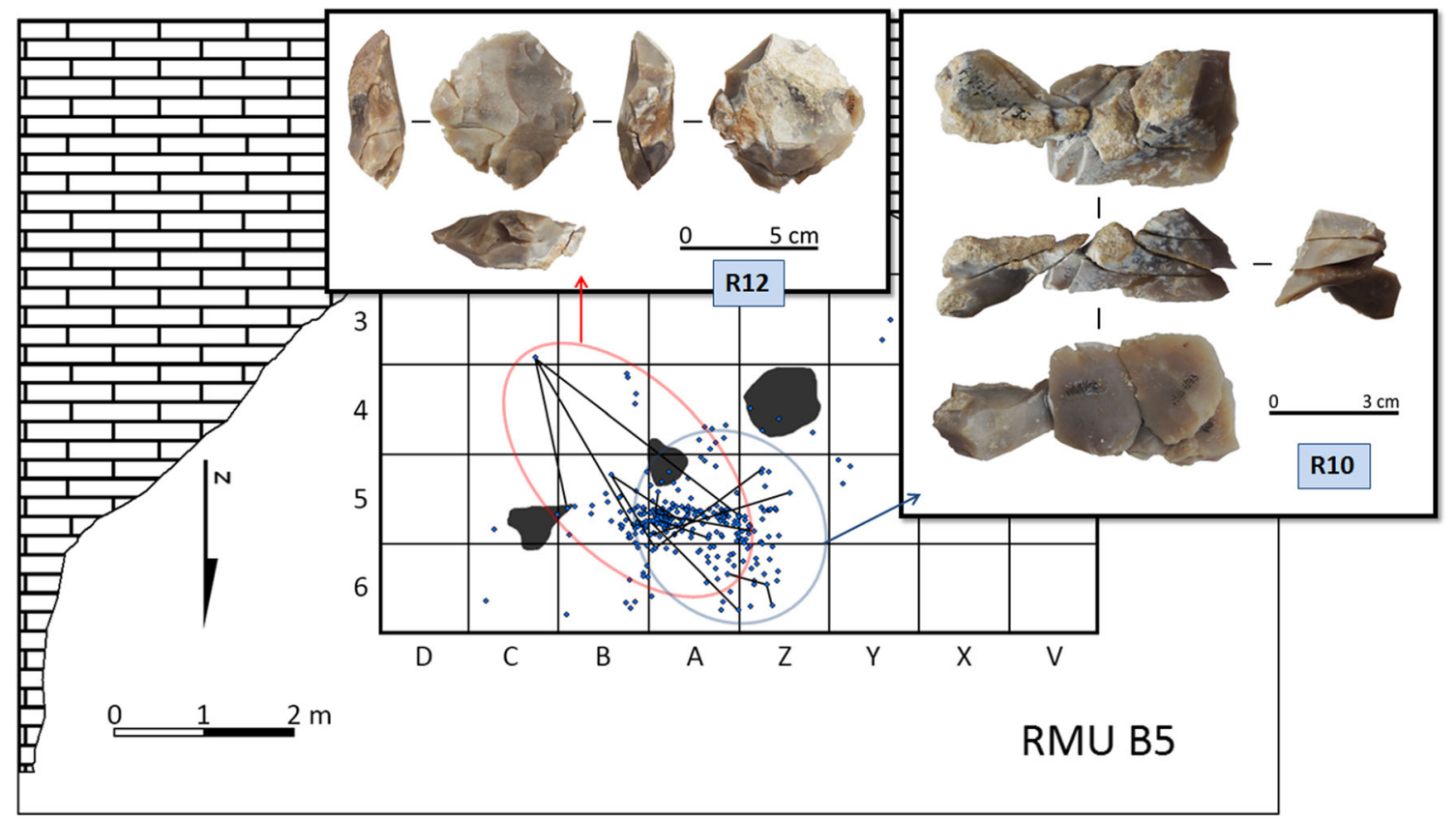

Fig. 6 Spatial distribution of R12 and R10 (RMU B5)

\section{Discussion}

Defined high-resolution analytical contexts representing archaeostratigraphically synchronic anthropogenic assemblages do not correspond necessarily to single human occupation episodes. Diachronic indicators identified within them have shown that even when working at a temporal scale of analysis close to the ethnographic time, the "palimpsest problem" persists in most cases. This difficulty has been evidenced by performed technical and spatial analyses involving RMUs, refits, hearths and faunal remains, used to distinguish between activities carried out during a single human occupation (intra-occupational diachrony), and those corresponding to several occupations (inter-occupational diachrony). Resulting data have indicated the presence of interoccupational diachronic indicators in all the analytical units, except for the AU IVc1. The absence of these temporal markers allows proposing as hypothesis that IVc1 anthropogenic material was deposited during a single occupation episode.

In this sense, it should be highlighted that IVc1 record is clearly structured as a hearth-related assemblage (Vaquero and Pastó 2001), widely considered as the most reliable
Fig. 7 Spatial distribution of RMU B4. Distribution of Refit R7 has been also indicated

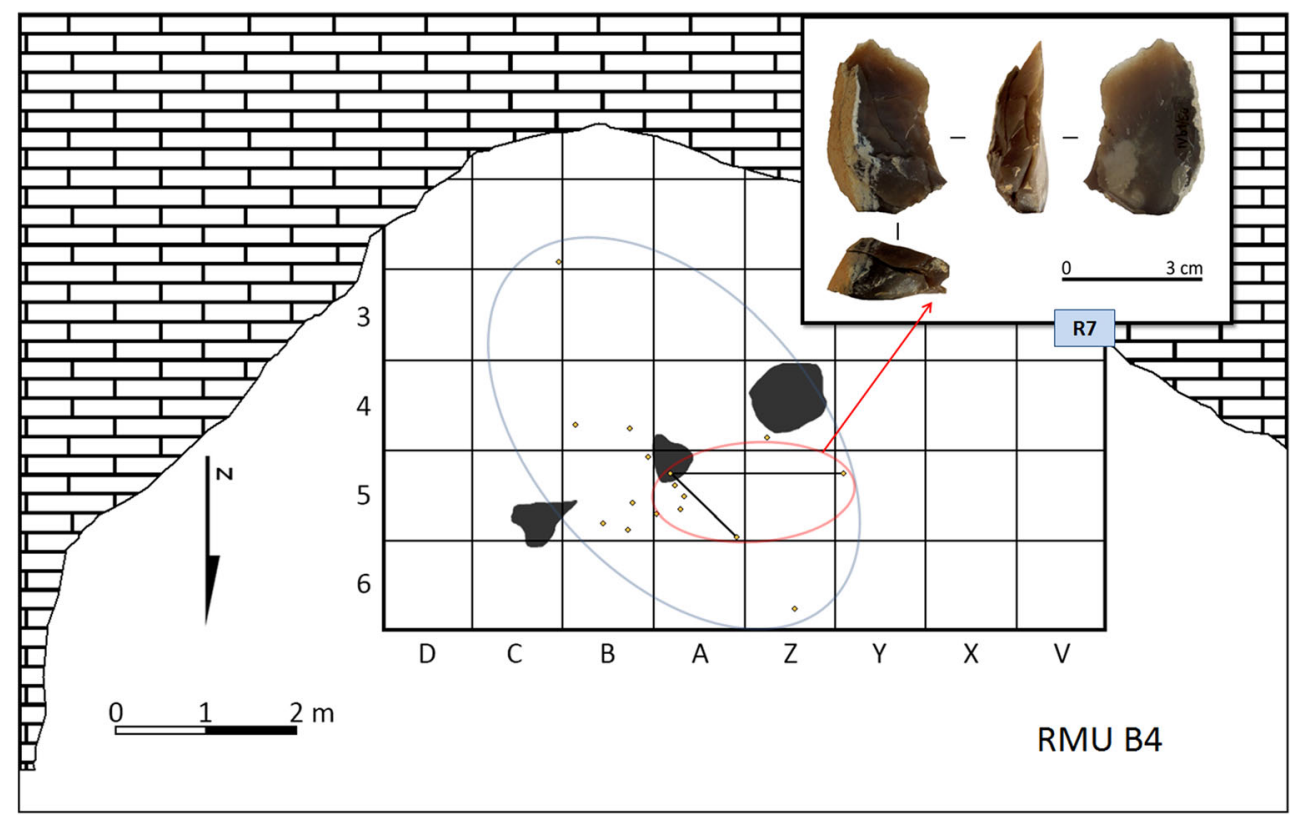




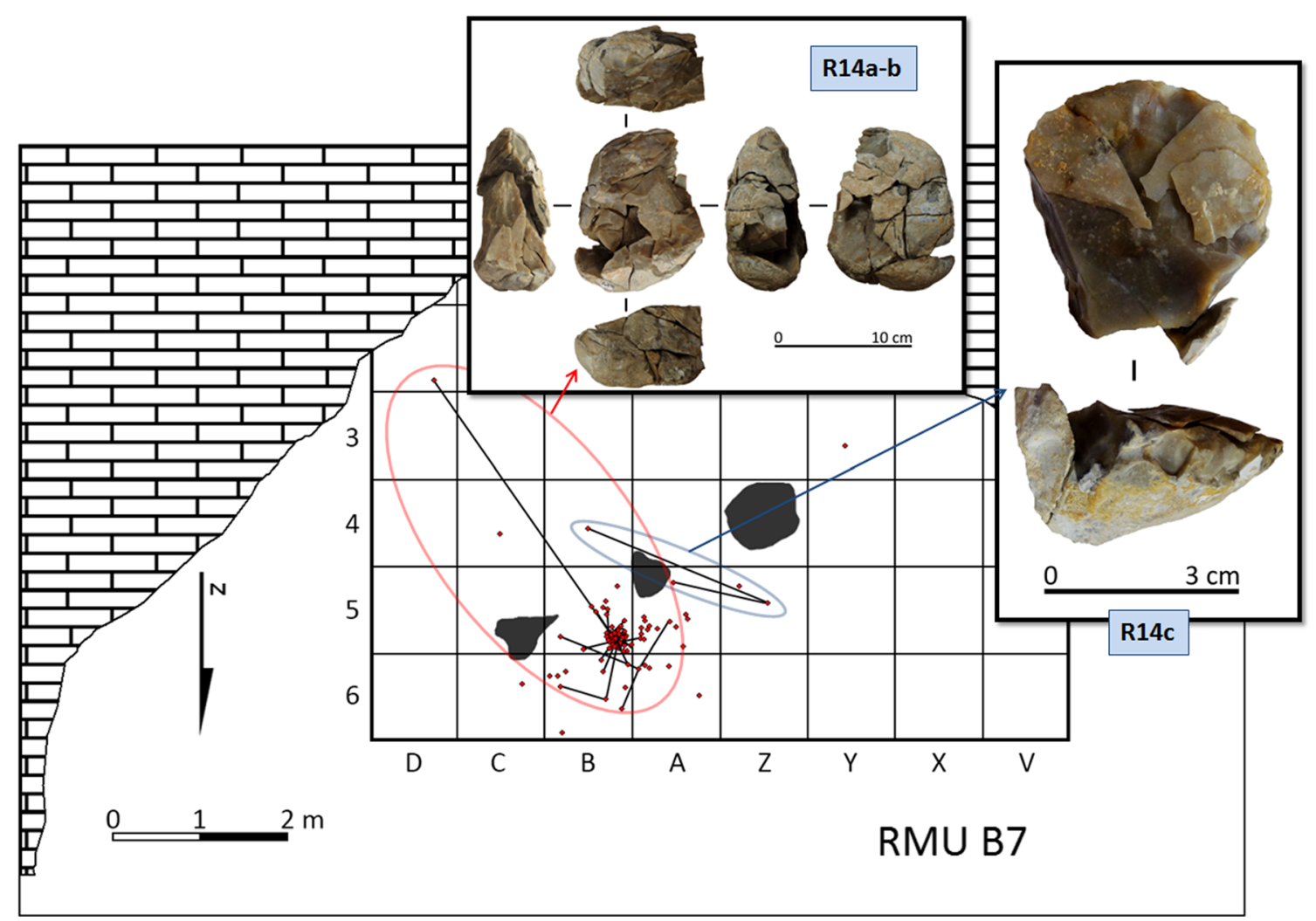

Fig. 8 Spatial distribution of RMU B7

material imprint of a single human occupation from the Middle Palaeolithic (see Machado et al. 2015). It can be also noted the scarce taxonomical variability shown by the faunal record (90\% Testudinidae) (Sanchis et al. 2015), the lack of evidences of on-site knapping activity such as refits, the low amount of lithic remains and their technical and morphological features (prevalence of tools brought to the site already configured and the low number of RMUs, formed by a few items). Further, performed geoarchaeological analyses (including micromorphological data) at the top of the Lithostratigraphic IVc (where the deposition of materials from the AU IVc1 occurred) have not revealed significant postdepositional alterations (Machado et al. 2013).

A hypothetical consideration of AU IVc2 assemblage as result from a single human occupation could be supported on the scarcity of material remains, the presence of a single hearth and the low amount (18) and features (3 RMUs without any refitting set and 5 transported tools) shown by lithics. However, other indicators have suggested to be cautious in this sense (in addition to the variability of faunal taxa and the mentioned alteration produced by roof collapse) (Table 4). First, the synchrony of the accumulation nearby the back wall and the remaining IVc2 assemblage can be discussed. In spite of the evidenced archaeostratigraphic relationship between them, the original position of the assemblage that was recovered close to the back wall could have been modified by post-depositional alterations (sporadic water flows and bioturbation). Location of this assemblage directly above of materials related to one of the hearths from the UA IVd1 (H14) reinforces its separation from the remaining IVc2 record. Further, the only two artefacts from the mentioned accumulation cannot be related to any other AU IVc2 lithic remain by belonging to the same RMU or refitting set.

Archaeostratigraphically correlated assemblages shaping AUs IVb and IVd 1 could be initially considered as results from single long-term occupations. However, the existence in both units of inter-occupational indicators as several hearths, faunal records showing an appreciable taxonomical variability (Table 4) and significant evidences of knapping have suggested that their formation lengths could represent more than a single human occupation.

Performed archaeostratigraphic and spatial studies in Ivb have allowed us to identify three main depositional episodes including several specific events. The oldest episode is formed by a refit that represents a cortex removal stage (RMU B4) and several refitting sets belonging to the same single flint mass (RMU B5). All of them are spatially related to H5 (Fig. 6). RMU B5 also shows the widest spatial scattering within the $\mathrm{AU}$ Ivb and H5 is the worst preserved hearth of the assemblage. Both features can be explained by the alteration produced by the following occupations of the rock shelter.

RMU B5 represents an in situ Levallois reduction of an almost complete nodule (Figs. 6 and 10). Physical disconnection between their refitting sets has been interpreted as the 
Table 5 Quantitative and technical data of studied refitting sets sorted by

archaeostratigraphic units

\begin{tabular}{|c|c|c|c|c|}
\hline $\mathrm{AU}^{*}$ & Refit & RMU & Technical features & Represented reduction stage \\
\hline \multirow[t]{14}{*}{$\mathrm{IVb}$} & $\mathrm{R} 1$ & $\mathrm{~B} 1$ & 2 cortical flakes & Cortex removal \\
\hline & $\mathrm{R} 2$ & & 3 flakes & Cortex removal \\
\hline & $\mathrm{R} 3$ & & Complete flake and 2 refitted flake fragments & Production \\
\hline & $\mathrm{R} 4$ & & Core and flake & Production \\
\hline & R5 & $\mathrm{B} 2$ & Refitted fractured flake & Production \\
\hline & R6 & B3 & 4 flakes & Production \\
\hline & R7 & B4 & 2 cortical flakes and flake & Cortex removal \\
\hline & $\mathrm{R} 8$ & B5 & 5 cortical flakes & Cortex removal \\
\hline & R9 & & Flake with natural surface and flake & Cortex removal \\
\hline & $\mathrm{R} 10$ & & 7 flakes & Production \\
\hline & R11 & & 5 flakes & Production \\
\hline & $\mathrm{R} 12$ & & Core and 5 flakes & Production \\
\hline & $\mathrm{R} 13$ & B6 & Core & Production \\
\hline & R14 & B7 & Full block fractured in 3 fragments & Production \\
\hline \multirow[t]{11}{*}{ IVd1 } & $\mathrm{R} 15$ & D1 & Core and flake & Production \\
\hline & $\mathrm{R} 16$ & D2 & 2 cortical flakes & Cortex removal \\
\hline & $\mathrm{R} 17$ & D3 & 2 flakes & Production \\
\hline & $\mathrm{R} 18$ & D4 & 3 cortical flakes & Cortex removal \\
\hline & R19 & & 7 flakes & Production \\
\hline & $\mathrm{R} 20$ & & 17 elements from a single block fragment & Almost complete sequence \\
\hline & $\mathrm{R} 21$ & & Core, cortical fragment and flake & Almost complete sequence \\
\hline & $\mathrm{R} 22$ & D5 & 2 cortical flakes & Cortex removal \\
\hline & $\mathrm{R} 23$ & & 2 refitted fragments from a flake & Production \\
\hline & $\mathrm{R} 24$ & & 7 flakes & Production \\
\hline & $\mathrm{R} 25$ & D6 & 2 cortical flakes and 1 flake & Cortex removal \\
\hline
\end{tabular}

*Archaeostratigraphic unit evidence of transport and use of several blanks out of the site. These "material gaps" and the on-site knapping activity evidenced by refitting sets from this RMU could be interpreted as an indicator of intra-occupational diachrony. These mentioned features could be representing several trips geared to perform specific activities out of the site while the human group was settled on the rock shelter. However, remains from RMU B5 could be also interpreted as the result of on-site provisioning and recycling of a partially reduced core during subsequent occupations.

The next depositional episode from IVb is characterised by a directional non-Levallois reduction of an almost entire flint nodule (RMU B7) next to H3. This sequence was clearly conditioned by its poor quality for knapping. Most of resulted products from this process (including two cores) were clustered in a main accumulation. However, a third refitting set belonging to RMU B7 (refit R14c) was relatively scattered away from this accumulation and also showed a different technical trend (centripetal reduction of a flake core) (Fig. 8). This sequence could be also highlighted as a clear evidence of intentional production of small-sized flakes $(<$ $2.5 \mathrm{~cm}$ long) (e.g. Ríos et al. 2015; Vaquero et al. 2012c).
These three described knapping activities related to RMU B7 are probably reflecting different depositional stories in occupational terms. The two refitting sets that represent non-Levallois sequences spatially related to $\mathrm{H} 3$ (R14a and R14b; Figs. 8 and 12) seem to belong to the same human occupation. In this sense, it could be indicated that items integrating these refits and most of the remaining lithics from the RMU B7 are shaping the $\mathrm{H} 3$ hearth-related assemblage. Also, both sequences represent attempts of exploitation of two flint masses of poor quality following the same technical strategy (Fig. 12).

On the other hand, different spatial and technical features displayed by the third mentioned refitting group from RMU B7 (R14c) could be considered as indicators of interoccupational diachrony. From this perspective, what seems to be remarkable is its spatial location slightly away from the main accumulation (being the core the farthest item from the group). Further, this refitting set represents a deliberate production of small centripetal Levallois blanks from a thick cortical flake, which could be interpreted as an on-site recycling event occurred during a subsequent occupation (Fig. 8). 


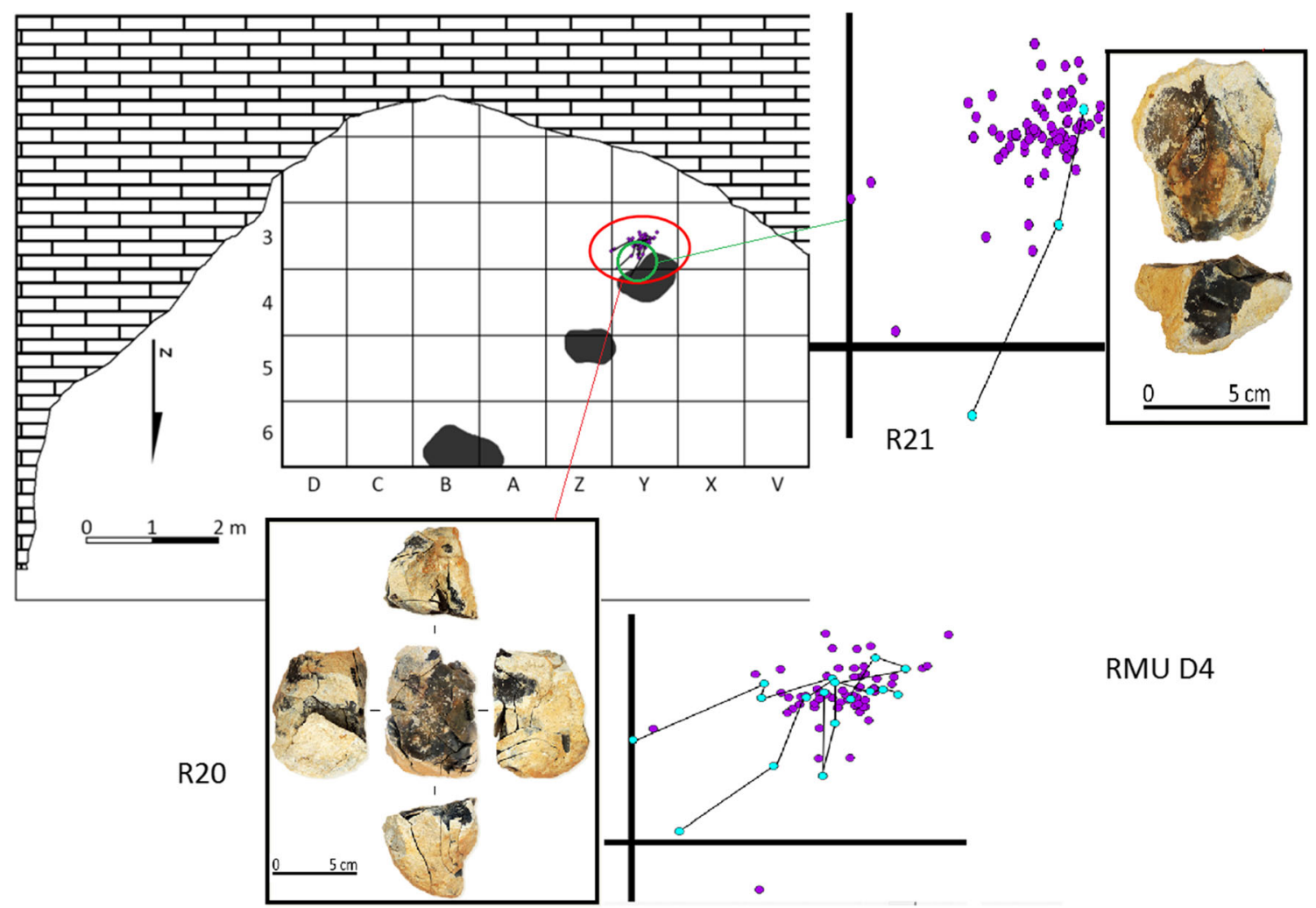

Fig. 9 Spatial distribution of RMU D4 next to H9. Spatial distributions of refitting sets from this RMU (R20 and R21) are also shown

Despite the above, the recognition of the R14c depositional event is only confirming the existence of a temporal gap between it and depositional events involving the remaining RMU B7 refitting sets. Therefore, this temporal gap could be framed within the same single occupation, thus representing an indicator of intra-occupational diachrony.

The most recent depositional episode from the AU Ivb is shaped by refitting sets from the RMUs B1 (Fig. 11) and B3 (R1-4 and R6, respectively), spatially linked to H4. The presence of six unburnt RMU B1 items resting on H5 leads to think about a depositional event occurred after the use of the hearth, thus confirming the diachronical relationship between H4 and H5 (Fig. 5). In this sense, the better preservation state shown by $\mathrm{H} 4$ could be also interpreted, probably performed during the most recent human occupation from IVb.

The four refitting sets from the RMU B1 (R1-4) represent several stages of a non-Levallois reduction sequence (cortex removal, plein débitage production and final exploitation stage including an almost exhausted core). On the other hand, RMU B3 represents a single short centripetal sequence corresponding to the typical convexity restitution of the Levallois cores (Table 2). Numerous "material gaps" between knapping stages represented by both RMUs (Fig. 11) have evidenced that most of the on-site knapping activity that shaped the most recent depositional episode from IVb was geared to generate products to be used outside. This technical trend was also observed in the case of the oldest IVb depositional episode

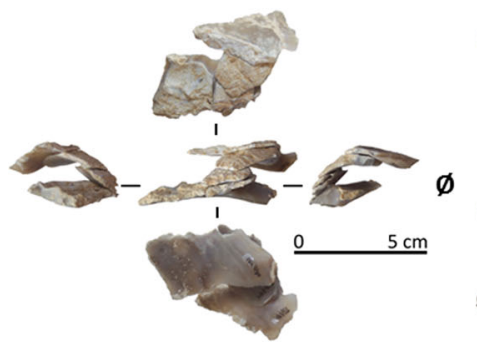

R8

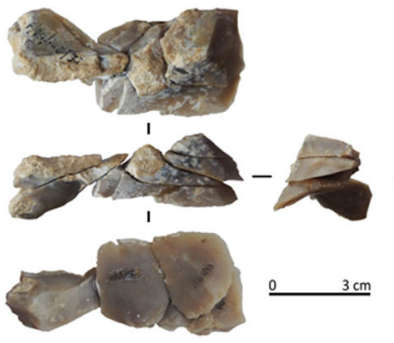

R9

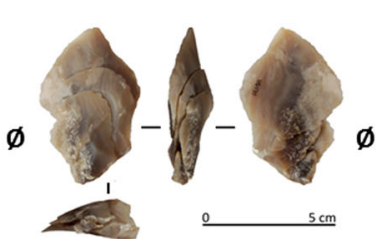

R11

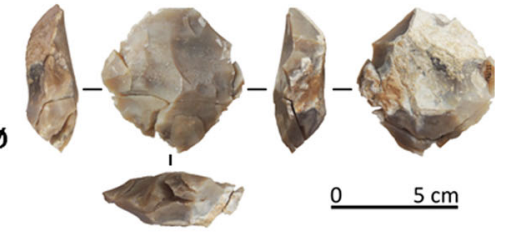

R12

RMU B5

Fig. 10 Four refitting sets representing different reduction stages from RMU B5. "Material gaps" between are also indicated (Ø) 


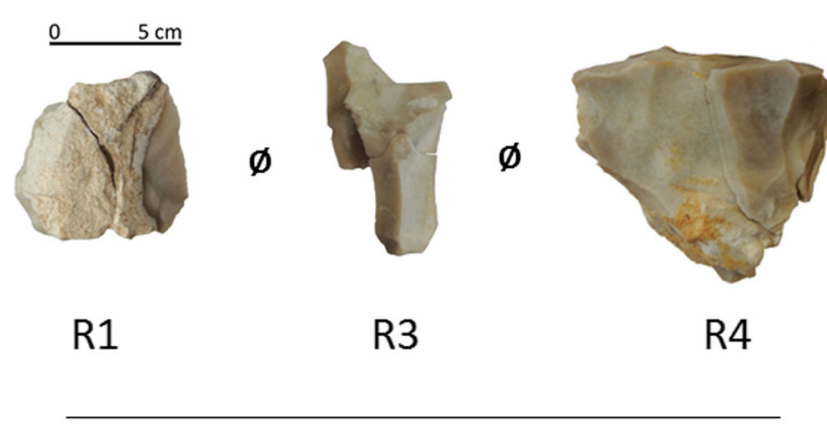

RMU B1

Fig. 11 Three refitting sets from RMU B1. "Material gaps" between are also indicated (Ø)

related to H5 (RMU B5). However, such feature has not been recorded at the H3-related assemblage, where an on-site reduction of a single nodule is almost entirely represented (RMU B7) (Fig. 12).

Provided data by our archaeostratigraphic and spatiotemporal analyses allow proposing that AU IVb was formed by at least three human occupations. The material imprint displayed by the described assemblages is in agreement to the consideration of hearth-related assemblages as the most usual trace of a single occupation from the Middle Palaeolithic. However, significant behavioural differences related to the management of lithic resources have been identified within these hearthrelated records.

Within the oldest one and the most recently deposited hearth-related assemblages, "material gaps" between refitting sets demonstrated knapping activities aimed at producing blanks to be used outside (RMUs B1, B3 and B5). On the other hand, RMU B7, linked to the remaining IVb depositional episode, shows an on-site reduction of a single nodule and also includes the possibility that a thick flake resulted from this process was used as a core during the subsequent occupation (i.e. a possible recycling episode). Different technical methods used (centripetal Levallois) and the spatial distribution shown by this refit (the only group of items from RMU B7 that does not show a clear spatial relationship to hearth $\mathrm{H} 3$ ) are remarkable in this sense.

The AU IVd1 is also shaped by archaeostratigraphically synchronic hearth-related assemblages (Fig. 5). All the refitting sets and most of the RMUs from this unit were clearly spatially related to one single combustion structure (Fig. 9). This absence of any bidirectional spatial relationship between accumulations around hearths shown by lithics has reinforced their consideration as independently deposited records. The farthest away accumulation around $\mathrm{H} 14$ can be pointed out as the most illustrative example of such possibility.

Indeed, such depositional interpretation is also supported on potential inter-occupational diachronic indicators identified within the AU IVd1, such as the already noted presence of several hearths (Fig. 5), the taxonomical variability revealed by faunal remains (Table 4) and their relative high degree of scattering between hearths H8, H9 and H11. Therefore, this lack of any strong indicator of intra-occupational diachrony leads to think that the formation of the AU IVd1 assemblage corresponds to a minimal amount of four human occupation episodes.

\section{Conclusions}

Our results have demonstrated the feasibility of isolating hightemporal resolution analytical units from which to approach more suitable time scales for analysing behavioural and cultural dynamics of Palaeolithic groups. Performed integrated technical and spatiotemporal analysis has also highlighted that lithic refits can provide significant intra-occupational and inter-occupational diachrony indicators for unravelling the formation lengths of horizontal palimpsests. In this sense, it should be remarked that this approach is based on an excavation surface corresponding to the almost entire potentially occupied area.
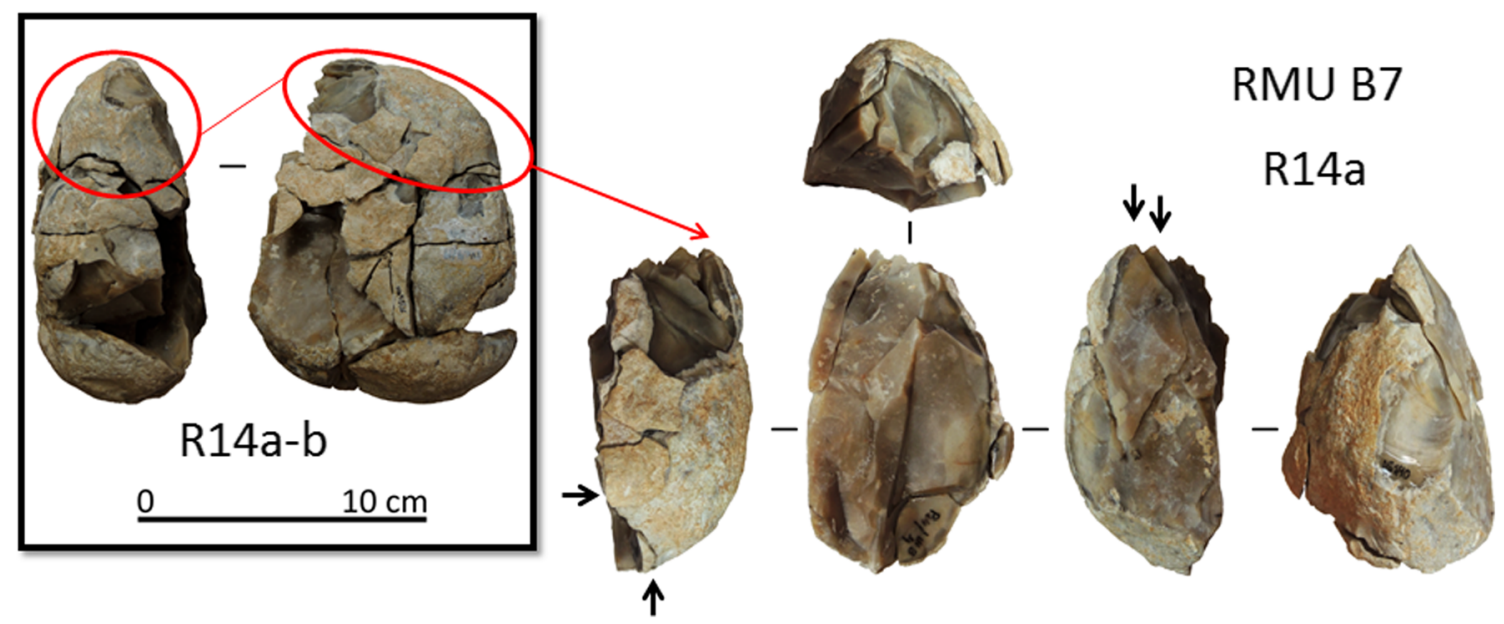

Fig. 12 Refitting R14a from RMU B7 
Presented temporal approach has permitted to raise several interpretations about the meaning of our high-resolution units in occupational terms:

- The AU IVd1 assemblage represents, at least, four single human occupation episodes.

- Assemblage from the AU IVc2 has no lithic refits. Only the accumulation spatially linked to H15 could correspond to a single occupation episode, although this hypothesis needs to be explored in depth.

- The AU IVc1 has not yielded any clear indicator of interoccupational diachrony. Its spatial distribution and material features allow us to consider such unit as the material imprint of a single occupation episode.

- The AU IVb represents a diachronic succession of at least three human occupation episodes.

The interpretation of the studied Middle Palaeolithic assemblages responds to a model of short-term occupations, focused on activity areas shaped as hearth-related assemblages. Also, observed behavioural trends and specific actions concerning lithic resources management could support inferences about site-function variability. In this regard, what could be highlighted are the recorded intentional production of small-sized flakes in AU IVb $(<2.5 \mathrm{~cm}$ long), the proposed interpretation of the RMU B5 (AU IVb) as an indicator of intra-occupational diachrony (several trips to outside framed within a single human occupation of the rock shelter) and the prevalence of on-site knapping activity shown within specific units (IVb and IVd1) and its lack within others (IVc1 and IVc2).

Acknowledgements We thank the members of El Pastor teamwork for their field and post-excavation tasks, and Museu Arqueològic Municipal Camil Visedo Moltó d'Alcoi and the Alcoian town hall for their support. We also thank Francesca Romagnoli, Manuel Vaquero, and the anonymous reviewers who helped to improve the earlier versions of this paper.

Funding information Archaeological research at El Pastor rock shelter is funded by the Spanish government project Neandertales en la montaña alicantina: un enfoque multianalitico (MEC-FEDER HAR2015-68321$\mathrm{P})$, and by the Valencian government through public research funding (DOGV P-0300900-H).

\section{References}

Adler DS, Prindiville TJ, Conard NJ (2003) Patterns of spatial organization and land-use during the Eemian interglacial in the Rhineland: new data from Wallertheim, Germany. Eurasian Prehistory 1(2):2578

Amick DS (2007) Investigating the behavioral causes and archaeological effects of lithic recycling. In McPherron SP (ed.) Tools versus cores. Alternative approaches to stone tool analysis: 223-252. Cambridge Scholars, Cambridge

Audouze F, Enloe JG (1997) High resolution archaeology at Verberie: limits and interpretations. World Archaeol 29(2):195-207

Bailey GN (2007) Time perspectives, palimpsests and the archaeology of time. J Anthropol Archaeol 26:198-223
Bargalló A, Gabucio MJ, Rivals F (2016) Puzzling out a palimpsest: testing an interdisciplinary study in level $\mathrm{O}$ of Abric Romaní. Quat Int 417:51-65

Binford LR (1980) Willow smoke and dog's tails: hunter-gatherer settlement dynamics and archaeological site formation. Am Antiq 45(1): 4-20

Binford LR (1981) Behavioral archaeology and the "Pompeii premise". J Anthropol Res 37:195-208

Bleed P (2002) Obviously sequential, but continuous or staged? Refits and cognition in three late Palaeolithic assemblages from Japan. J Anthropol Archaeol 21:329-343

Carrancho A, Villalaín JJ, Vallverdú J, Carbonell E (2016) Is it possible to identify temporal differences among combustion features in Middle Palaeolithic palimpsests? The archaeomagnetic evidence: a case study from level $\mathrm{O}$ at the Abric Romaní rock-shelter (Capellades, Spain). Quat Int 417:39-50

Chacón GM, Bargalló A, Gabucio MJ, Rivals F, Vaquero M (2015) Neanderthal behaviors from a spatio-temporal perspective: an interdisciplinary approach to interpret archaeological assemblages. In: Conard NJ, Delagnes A (eds) Settlement dynamics of the Middle Palaeolithic and Middle Stone Age IV: 253-294. Kerns Verlag, Tübingen

Conard NJ, Adler DS (1997) Lithic reduction and hominid behavior in the Middle Palaeolithic of the Rhineland. J Anthropol Res 53:147176

Conard NJ (2001) Advances and problems in the study of Paleolithic settlement systems. In: Conard NJ (ed) Settlement dynamics of the Middle Paleolithic and Middle Stone Age: 7-20. Kerns Verlag, Tübingen

Gabucio MJ, Fernández MC, Rosell J (2017) Turning a rock shelter into a home. Neanderthal use of space in Abric Romaní levels M and O. Hist Biol 30(6):743-766

Gabucio MJ, Cáceres I, Rivals F, Bargalló A, Rosell J, Saladié P, Vallverdú J, Vaquero M, Carbonell E (2018) Unraveling a Neanderthal palimpsest from a zooarchaeological and taphonomic perspective. Archaeol Anthropol Sci 10(1):197-222

Galván B, Hernández CM, Francisco MI, Molina FJ, Tarriño A (2009) La producción lítica del Abric del Pastor (Alcoy, Alicante). Un ejemplo de la variabilidad musteriense Tabona 17:11-61

Goldberg P, Macphail RI (2005) Practical and theoretical geoarchaeology. Blackwell, Oxford

Goldberg P, Berna F (2010) Micromorphology and context. Quat Int 214(1-2):56-62

Henry DO (2012) The palimpsest problem, hearth pattern analysis, and Middle Paleolithic site structure. Quat Int 247:246-266

Hernández CM, Galván B, Mallol C, Machado J, Molina FJ, Pérez L, Morales JV, Sanchis A, Vidal P, Rodríguez A (2014) Abric de El Pastor in the Neanderthal occupation of the Alcoy valleys, Alicante (Spain). In Sala R, Carbonell E, Bermúdez de Castro JM, Arsuaga JL (eds.). Pleistocene and Holocene hunter-gatherers in Iberia and the Gibraltar strait: the current archaeological record: 319-323. Fundación Atapuerca, Burgos

Husmann H (1990) Some stones, few bones: indications of spatial use of limited areas by examples from the site Niederbieber (37/40-42/45). In Cziesla E, Eickhoff S, Arts N, Winter D (eds.) The big puzzle. International symposium on refitting stone artefacts: studies in modern archaeology: 465-476. Holos, Bonn

Isaac G (1981) Stone Age visiting cards: approaches to the study of early land use patterns. In: Hodder I, Isaac G, Hammond N (eds) Pattern of the past: studies in honour of David Clarke: 131-155. Cambridge University Press, Cambridge

López E, Bargalló A, De Lombera A, Mosquera M, Ollé M, Rodríguez XP (2017) Quartz and quartzite refits at Gran Dolina (Sierra de Atapuerca, Burgos): connecting lithic artefacts in the middle Pleistocene unit of TD10.1. Quat Int 433(A):85-102 
Lucas G (2012) Understanding the archaeological record. Cambridge University Press, Cambridge

Machado J, Hernández CM, Mallol C, Galván B (2013) Lithic production, site formation and Middle Palaeolithic palimpsest analysis: in search of human occupation episodes at Abric del Pastor stratigraphic unit IV (Alicante, Spain). J Archaeol Sci 20:2254-2273

Machado J, Mallol C, Hernández CM (2015) Insights into Eurasian Middle Palaeolithic settlement dynamics: the palimpsest problem. In: Conard NJ, Delagnes A (eds) Settlement dynamics of the Middle Paleolithic and Middle Stone Age IV: 361-382. Kerns Verlag, Tübingen

Machado J, Pérez L (2016) Temporal frameworks to approach human behaviour concealed in Middle Palaeolithic palimpsests: a highresolution example from El Salt stratigraphic unit X (Alicante, Spain). Quat Int 417:66-81

Machado J, Molina FJ, Hernández CM, Tarriño A, Galván B (2017) Using lithic assemblage formation to approach Middle Palaeolithic settlement dynamics: El Salt stratigraphic unit X (Alicante, Spain). Archaeol Anthropol Sci 9:1715-1743

Mallol C, Hernández CM, Cabanes D, Sistiaga A, Machado J, Rodríguez A, Pérez L, Galván B (2013a) The black layer of Middle Palaeolithic combustion structures. Interpretation and archaeostratigraphic implications. J Archaeol Sci 20:2515-2537

Mallol C, Hernández CM, Cabanes D, Machado J, Sistiaga A, Pérez L, Galván B (2013b) Human actions performed on simple combustion structures: an experimental approach to the study of Middle Palaeolithic fire. Quat Int 315:3-15

Mallol C, Mentzer S (2015) Contacts under the lens: perspectives on the role of microstratigraphy in archaeological research. Archaeol Anthropol Sci 9(8):1645-1669

Mallol C, Hernández CM (2016) Advances in palimpsest dissection. Quat Int 417:1-2

Martínez J, Mora R, De la Torre I (2004) Methodological approach for understanding Middle Palaeolithic settlement dynamics at La Roca dels Bous (Noguera, Catalunya, Northeast Spain). In: Conard NJ (ed) Settlement dynamics of the Middle Palaeolithic and Middle Stone Age: 393-414. Kerns Verlag, Tübingen

Martínez J, Mora R, Roy M, Benito A (2015) From site formation processes to human behavior: towards a constructive approach to depict palimpsests in Roca dels Bous. Quat Int 417:82-93

Molina FJ, Tarriño A, Galván B, Hernández CM (2010) Áreas de aprovisionamiento de sílex en el Paleolítico medio en torno al Abric del Pastor (Alcoi, Alicante). Estudio macroscópico de la producción lítica de la colección Brotons Recerques del Museu d'Alcoi 19:65-80

O'Connell JF (1987) Alyawara site structure and its archaeological implications. Am Antiq 52(1):74-108

Pérez L, Sanchis A, Hernández CM, Galván B (2017) Paleoecología de macromamíferos aplicada a los conjuntos zooarqueológicos de El Salt y el Abric del Pastor (Alcoy, Alicante). In: Sanchis A, Pascual JL (eds) Interaccions entre felins i humans: homenatge a Innocenci Sarrión Montañana: 327-353. Museu de Prehistòria de València, València

Ríos J, Eixea A, Villaverde V (2015) Ramification of lithic production and the search of small tools in Iberian peninsula Middle Paleolithic. Quat Int 361:188-199

Roebroeks W (1988) From find-scatters to early hominid behaviour: a study of Middle Palaeolithic riverside settlements at MaastrichtBelvédère (the Netherlands). Leiden University Press, Leiden

Romagnoli F, Vaquero M (2016) Quantitative stone tools intra-site point and orientation patterns of a Middle Palaeolithic living floor: a GIS multi-scalar spatial and temporal approach. Quartär 63:47-60

Romagnoli F, Bargalló A, Chacón GM, Gómez B, Vaquero M (2016) Testing a hypothesis about the importance of the quality of raw material on technological changes at Abric Romaní (Capellades,
Spain): some considerations using a high-resolution techno-economic perspective. J Lithic Stud 3(2):1-25

Romagnoli F, Gómez B, Bargalló A, Chacón MG, Vaquero M (2017) Here and now or a previously planned strategy? Rethinking the concept of ramification for micro-production in expedient contexts: implications for Neanderthal socio-economic behaviour. Quat Int 474(B):168-181

Rosell J, Blasco R, Fernández MC, Vaquero M, Carbonell E (2012) Connecting areas: faunal refits as a diagnostic element to identify synchronicity in the Abric Romaní archaeological assemblages. Quat Int 252:56-67

Sánchez L, Canals A, Pérez A, Márquez B, Mosquera M, Karampaglidis T, Arsuaga JL, Baquedano E (2017) Deshaciendo el palimpsesto: una aproximación a la secuencia cultural de la ocupación neandertal del abrigo de Navalmaíllo, Pinilla del Valle (España). Trab Prehist 74(2):225-237

Sanchis A, Morales JV, Pérez L, Hernández CM, Galván B (2015) La tortuga mediterránea en yacimientos valencianos del Paleolítico medio: distribución, origen de las acumulaciones y nuevos datos procedentes del Abric del Pastor (Alcoi, Alacant). In: Sanchis A, Pascual JL (eds) Preses petites i grups humans en el passat: 97120. Museu de Prehistòria de València, València

Sañudo P, Blasco R, Fernández J (2015) Site formation dynamics and human occupations at Bolomor Cave (Valencia, Spain): archaeostratigraphic analysis of levels I to XII (100-200 ka). Quat Int 417:94-104

Schiffer MB (1985) Is there a "Pompeii premise" in archaeology? J Anthropol Archaeol 41:18-41

Schmider B, De Croisset E (1990) The contribution of lithic refittings for spatial analysis of campsite H 17 and D 14 at Marsangy. In Cziesla E, Eickhoff S, Arts N, Winter D (eds.) The big puzzle. International symposium on refitting stone artefacts: studies in modern archaeology: 431-445. Holos, Bonn

Shott MJ (2008) Lower Paleolithic industries, time, and the meaning of assemblage variation. In: Holdaway S, Wandsnider L (eds) Time in archaeology: time perspectivism revisited: 46-60. University of Utah Press, Salt Lake City

Spagnolo V, Marciani G, Aureli D, Berna F, Boscato P, Ranaldo F, Ronchitelli A (2016) Between hearths and volcanic ash: the SU 13 palimpsest of the Oscurusciuto rock shelter (Ginosa - southern Italy): analytical and interpretative questions. Quat Int 417:105-121

Stern N (1993) The structure of the Lower Pleistocene archaeological record: a case of study from the Koobi for a formation. Curr Anthropol 34(3):201-224

Stern N (1994) The implications of time-averaging for reconstructing the land-use patterns of early tool-using hominids. J Hum Evol 27:89 105

Stevenson MG (1991) Beyond the formation of hearth-associated artifact assemblages. In: Kroll EM, Price TD (eds) The interpretation of archaeological spatial patterning: 269-299. Plenum Press, New York

Sumner TA, Kuman K (2014) Refitting evidence for the stratigraphic integrity of the Kudu Koppie Early to Middle Stone Age, northern Limpopo Province, South Africa. Quat Int 343:169-178

Takakura J (2018) Lithic refitting and its implications for the integrity and duration of site occupation: the case of the late Upper Paleolithic site of Kiusu-5 in Hokkaido, northern Japan. Quat Int 474(B):156-167

Thiébaut C, Claud E, Mourre V, Chacón MG, Asselin G, Brenet M, Paravel B (2010) Le recyclage et la réutilisation de nucléus et de bifaces au Paléolithique moyen en Europe occidentale: quelle fonction et quelle implications culturelles? Palethnologie, varia 2010:3-38

Vallverdú J, Allué A, Bischoff JL, Cáceres I, Carbonell E, Cebrià A, García-Antón D, Huguet R, Ibáñez N, Martínez K, Pastó I, Rosell J, Saladié P, Vaquero M (2005) Short human occupations in the 
Middle Palaeolithic level i of the Abric Romaní rock-shelter. J Hum Evol 48:157-174

Vaquero M, Chacón GM, Fernández C, Martínez K, Rando JM (2001) Intrasite spatial patterning and transport in the Abric Romaní Middle Palaeolithic site (Capellades, Barcelona, Spain). In: Conard NJ (ed) Settlement dynamics of the Middle Palaeolithic and Middle Stone Age: 573-595. Kerns Verlag, Tübingen

Vaquero M, Pastó I (2001) The definition of spatial units in Middle Palaeolithic sites: the hearth-related assemblages. J Archaeol Sci 28:1209-1220

Vaquero M (2008) The history of stones: behavioural inferences and temporal resolution of an archaeological assemblage from the Middle Palaeolithic. J Archaeol Sci 35(12):3178-3185

Vaquero M (2011) New perspectives on recycling of lithic resources using refitting and spatial data. Quartär 58:113-130

Vaquero M, Chacón MG, García-Antón MD, Gómez R, Martínez K, Cuartero F (2012a) Time and space in the formation of lithic assemblages: the example of Abric Romaní level J. Quat Int 247:162-181

Vaquero M, Allué E, Vallverdú J (2012b) Conclusions: landscapes, campsites, times, and Neanderthal behavior. In Carbonell E (ed.) High resolution archaeology and Neanderthal behavior. Time and space in level J of Abric Romaní (Capellades, Spain): 389-405. Springer, New York
Vaquero M, Chacón MG, Cuartero F, García MD, Gómez B, Martínez K (2012c) The lithic assemblage of level J. In Carbonell E (ed.) High resolution archaeology and Neanderthal behavior: time and space in level J of Abric Romaní (Capellades, Spain): 189-311. Springer Science+Business Media, Dordrecht

Vaquero M, Bargalló A, Chacón MG, Romagnoli F, Sañudo P (2015) Lithic recycling in a Middle Palaeolithic expedient context: evidence from the Abric Romaní (Capellades, Spain). Quat Int 361: 212-228

Vaquero M, Fernández MC, Chacón MG, Romagnoli F, Rosell J, Sañudo P (2017) Moving things: comparing lithic and bone refits from a Middle Paleolithic site. J Anthropol Archaeol 48:262-280

Vidal P, Hernández CM, Galván B, Mallol C (2015) Neanderthal firewood management: evidence from stratigraphic unit IV of Abric del Pastor (Eastern Iberia). Quat Sci Rev 111:81-93

Vidal P, Henry A, Théry-Parisot I (2017) Dead wood gathering among Neanderthal groups: charcoal evidence from Abric del Pastor and El Salt (Eastern Iberia). J Archaeol Sci 80:109-121

Publisher's note Springer Nature remains neutral with regard to jurisdictional claims in published maps and institutional affiliations. 